\begin{abstract}
Оптимізовано метод синтезу тонкодисперсного порошку нікеля, призначеного для виробництва твердих сплавів, прямим електролізом розчину амінокомплексу нікелю. Показано формування в оптимальніх умовах коралоподібних иастинок порошку розміром 40-70 мкм, що легко піддаються розмолу до сфероідних складових. Визначено максимальну температуру електроліту, показано позитивний вплив добавки Трилону Б на характеристики порошку. Визначено катодний та анодний вихід за струмом

Ключові слова: амінокомплекс нікелю, порочок нікелю, тверді сплави, дендрит, Трилон Б
\end{abstract}

$$
\square
$$

Оптимизирован метод синтеза тонкодисперсного порошка никеля, предназначенного для производства твердых сплавов, прямым электролизом раствора аминокомплекса никеля. Показано формирование в оптимальных условиях кораллоподобных частии, порошка размером 40-70 мкм, легко размалывающихся на сфероидные составляющие. определена максимальная температура электролита, показано положительное влияние добавки Трилона Б на характеристику порошка. Определены катодный и анодный выходы по току

Ключевые слова: аминокомплекс никеля, порошок никеля, твердые сплавы, дендрит, Трилон Б

\section{DEFINITION OF SYNTHESIS PARAMETERS OF ULTRAFINE NICKEL POWDER BY DIRECT ELECTROLYSIS FOR APPLICATION IN SUPERALLOY PRODUCTION}

V. Kovale n k o

PhD, Associate Professor** Department of Analytical Chemistry and Food Additives and Cosmetics*

E-mail: vadimchem@gmail.com

V. Kot ok

PhD, Associate Professor** Department of Processes, Apparatus and

General Chemical Technology*

E-mail: valeriykotok@gmail.com

S. VIasov

Doctor of Technical Sciences, Professor Department of underground mining

National Mining University

Yavornytskoho ave., 19, Dnipro, Ukraine, 49005

Department of building manufacture $* * \star$

E-mail: ocmy@ukr.net

*Ukrainian State University of Chemical Technology

Gagarina ave., 8, Dnipro, Ukraine, 49005

**Department of Technologies of Inorganic Substances and Electrochemical Manufacturing $* \star *$

$\star * *$ Vyatka State University

Moskovskaya str., 36, Kirov, Russian Federation, 610000

\section{Introduction}

Ultrafine metal powders are used in various fields of engineering and manufacturing. Nickel powder, owing to its high electrical conductivity, catalytic and electrocatalytic properties, magnetic characteristics and high corrosion resistance is used for various applications. For instance, it is used for the preparation of special cement [1], as a catalyst [2], and for the preparation of colloids [3].

Ultrafine nickel powder is also necessary for the manufacturing of super alloys [4,5], which are widely used in mining, aerospace and metal processing industries. Superalloys, which are also called pseudo-alloys are not true alloys but composite materials. Usually, composite materials of organic [6, 7], inorganic [8] or mixed organic-inorganic nature $[9,10]$ are composed of matrix material and filler material [11]. At the same time, superalloys have a different structure: the majority of hard material particles are held together by a molten metal binder $(\mathrm{Ni}$ in particular).

Superalloys are prepared by means of powder metallurgy: a mixture of hard component and metal [12] (sometimes oxide of metal binder [13]) is sintered under pressure to obtain metal-ceramic workpieces. The described technology leads to special requirements for nickel powder. Primarily, it must be free from volatile compounds or metals (zinc, magnesium), as this can lead to the formation of caverns inside the formed workpiece. Powder particles size should be 5-50 $\mu \mathrm{m}$. Additionally the mixture of hard component and nickel is ground in alcohol before forming a workpiece, so another requirement for nickel powder is susceptibility to grinding.

The main parameters of superalloys are mechanical durability and stability at high temperatures [14]. In particular, these properties are important for application in the mining industry, and especially in the aerospace field [15]. Superalloys are used for the manufacturing of turbines for jet 
and rocket engines. Thus, when manufacturing such critical parts, more stringent requirements are imposed on the composition of nickel powder, determined by synthesis methods and conditions [16].

\section{Literature review and problem statement}

When developing the method for preparing any material, the raw material is usually analyzed first and then the method is chosen with respect to the product requirements.

Based on principles of sustained development and the fact that nickel is a rather expensive metal, the best sources of nickel are various nickel-containing waste in various forms. Primarily, this can be liquid nickel-containing waste [17]. Superalloy scrap with the nickel binder is well suited for preparing nickel powder for manufacturing of superalloys. The scrap can be utilized in two ways [18, 19]:

- directly as a source of solid nickel;

- as a source of nickel salts after selective dissolution.

The other source of nickel can be scrap of batteries employing nickel oxide electrode, particularly alkaline batteries $[20,21]$. In this case, the active electrode material $\left(\beta-\mathrm{Ni}(\mathrm{OH})_{2}\right.$ [22] and $\left.\alpha-\mathrm{Ni}(\mathrm{OH})_{2}[23]\right)$ must be treated to obtain a solution of nickel salts. Nickel oxide electrodes of hybrid supercapacitors $[24,25]$ can be processed in the same way.

Many methods for the preparation of ultrafine nickel powder have been developed [26-40]. In [26], the evaporation-condensation method is proposed, however, this method requires special equipment and the process must be conducted under inert atmosphere. A method was developed for processing of solid nickel waste by treating them with molten metals [27], with zinc in particular [28]. The method consists in dissolving nickel in molten metal and then stripping the metal and obtaining nickel powder. Such method is not used to prepare nickel powder for superalloys, because it would contain admixtures of zinc or other metals. In [29], the solvothermal process for obtaining nickel powder has been described. A method for the preparation of nickel powder by reduction of nickel cation with hydrazine has also been developed [30]. In [31], the preparation of nickel powder from freshly precipitated nickel hydroxide by reduction with sodium hypophosphite has been described. However, this leads to the formation of Ni-P alloy powder, which is not suitable for the preparation of superalloys. It has been also proposed to use polyols as reducing agents [32], additionally, the paper also proposes the use of strong surfactants. This is likely because of absorption of surfactants on the surface of forming metal particles (as described in [33]). In this case, the powder would be contaminated with surfactant residue, which makes it unsuitable for the preparation of superalloys. The same can also be said about nickel powder, prepared by reduction with $\mathrm{Ti}(\mathrm{III})$ [34]. In this case, the nickel powder would be contaminated with volatile titanium compounds. One of the most common methods for the preparation of nickel powder is reduction with hydrogen from salts [35], and also oxides [36]. The prepared nickel powder is susceptible to grinding, doesn't contain any impurities, however, the production requires a hydrogen station and heating. A carbonyl method for the preparation of nickel powder is used [37], however, it employs highly toxic nickel carbonyl.

One of the most promising methods for the preparation of Ni powder is electrolysis, which allows controlling the parameters of the resulting powder. Methods of electro- lyte-plasma synthesis [38, 39] and electrolysis with impulse current at elevated voltage [40] have been proposed. However, the usage of plasma-electrochemical process or high-voltage electrolysis complicates the equipment and significantly increases the cost of the process.

The more acceptable method is direct electrolysis of a nickel salt solution. In order to obtain nickel powder, it is necessary to conduct electrolysis at current densities that significantly exceed the limiting current density. However, under such conditions, the near-cathode volume is alkalineded and nickel is precipitated in the form of nickel hydroxide. In order to avoid this, the electrolysis of nickel salt (most commonly - nickel sulfate) is conducted in the presence of ammonium sulfate. In a basic medium, the ammonium cation transforms into ammonia, which forms an ammine complex with nickel, which can pass through the alkaline near-cathode layer to the cathode and upon discharge forms nickel powder [37].

Electrolysis of nickel sulfate with ammonium sulfate allows preparing nickel powder that is suitable for the preparation of superalloys. However, the detailed data on electrolysis parameters, electrolyte composition for the preparation of powder specifically for use in superalloys (susceptible to grinding, without admixtures of compact metal) are uncertain.

\section{The aim and objectives of the study}

The aim of the work is to determine synthesis conditions of ultrafine nickel powder for use in the preparation of superalloys.

To achieve this aim, the following objectives were set:

- to study the influence of the electrolyte temperature on the properties of the prepared nickel powder;

- to study the influence of electrolyte composition on the synthesis process and properties of nickel powder;

- to conduct a comparative analysis of prepared nickel powder samples and determine the optimal electrolysis conditions.

\section{Materials and methods}

\section{1. Electrolyte composition for preparation of nickel} powder

For the preparation of nickel powder, the base solution of the following composition was used: $\mathrm{Ni}^{2+} 0.1 \mathrm{~mol} / \mathrm{L}, \mathrm{NH}_{4}^{+}$ $1 \mathrm{~mol} / \mathrm{L}, \mathrm{NH}_{3} \cdot \mathrm{H}_{2} \mathrm{O}$ up to $\mathrm{pH} 11$. As a source of $\mathrm{Ni}^{2+}$, nickel sulfate $\mathrm{NiSO}_{4} \cdot 7 \mathrm{H}_{2} \mathrm{O}$, obtained from spent alkaline batteries was used, a source of $\mathrm{NH}_{4}^{+}-$ammonium sulfate, $\mathrm{pH}$ of the solution was corrected with aqueous ammonia solution.

\section{2. Study of electrode reactions during nickel pow-} der synthesis

Electrode reactions were studied by recording cathodic and anodic polarization curves. The studies were conducted in a special three-electrode cell with the auxiliary platinum electrode. $\mathrm{Ag} / \mathrm{AgCl}(\mathrm{KCl}$ sat.) electrode was used as a reference electrode. The reference electrode was placed into a glass with a saturated $\mathrm{KCl}$ solution. The other glass, with the working and auxiliary electrodes, was filled with the electrolyte for nickel powder synthesis. Stainless steel was used as a working electrode for the cathodic process, and 
nickel for anodic. In order to avoid the edge effect, the working electrode was placed into a Teflon cassette, composed of two rectangular parts, one of which had a round hole with a diameter of $0.012 \mathrm{~m}$. In order to create an electrical contact between two glasses, a Luggin-Haber capillary filled with the studied solution was used. Polarization curves were recorded using the Ellins P-8 digital potentiostat (Russia). Potential scan rates were $1 \mathrm{mV} / \mathrm{s}$ and $5 \mathrm{mV} / \mathrm{s}$.

\section{3. Electrolysis method for preparation of nickel} powder

The electrolysis had been conducted in the flow-through polypropylene cell. The cell was equipped with stainless steel cathode and two nickel anodes. The electrolysis had been conducted at a current density of $100 \mathrm{~A} / \mathrm{dm}^{2}$. During the electrolysis, large amounts of heat were generated. In order to evaluate the influence of synthesis temperature, the electrolysis was conducted under the following conditions:

- no cooling;

- evaporative cooling: the cell was placed into a tissue cover that was in the water and under airflow;

- water-cooling: the cell was placed in a large container with cold water;

- snow-water cooling: the cell was placed in a large container with a mixture of water and snow.

\section{4. Study of nickel powders}

After electrolysis, nickel powder was removed from the cathode, washed a few times with distilled water and dried at room temperature.

Morphology and particle size were studied using the JEOL JSM-6510LV scanning electron microscope ("JEOL", Japan). Chemical composition was studied by means of EDX analysis using the Hitachi S4500 microscope (Japan).

\section{Results of studying the conditions of electrochemical synthesis of nickel powder}

\section{1. Study on the influence of temperature on charac-} teristics of nickel powder

The results of evaluating the influence of the cell temperature on the characteristics of nickel metal powder are presented in Table 1.

Table 1

Influence of the cooling method and temperature on characteristics of nickel powder.

\begin{tabular}{|c|c|c|}
\hline Cooling method & Temperature, ${ }^{\circ} \mathrm{C}$ & Powder quality \\
\hline no cooling & 98 & $\begin{array}{c}\text { Very coarse powder with } \\
\text { inclusions of compact metal }\end{array}$ \\
\hline $\begin{array}{c}\text { evaporative } \\
\text { cooling }\end{array}$ & $81-82$ & $\begin{array}{c}\text { Coarse powder, low suscepti- } \\
\text { bility to grinding }\end{array}$ \\
\hline $\begin{array}{c}\text { water-cooling } \\
\text { snow-water } \\
\text { cooling }\end{array}$ & 74 & $\begin{array}{c}\text { Moderately fine powder, can } \\
\text { be ground with effort }\end{array}$ \\
\hline
\end{tabular}

Lower temperature leads to a finer powder and higher susceptibility to grinding. At high temperatures, the formation of compact metal is observed.
5. 2. Study on the influence of electrolyte composition on electrode reactions during nickel powder synthesis

When studying the influence of temperature during electrolysis without cooling, it was discovered that the solution color had changed from purple to blue. This indicated decreasing concentration of ammonia. Therefore, the influence of ammonia concentration on cathodic and anodic processes was studied. For that, solutions with ammonia concentrations of $50 \%, 110 \%, 150 \%$ and $200 \%$ of the base concentration were prepared.

Polarization curves in solutions with different concentrations of ammonia are presented in Fig. 1 (anodic curves) and Fig. 2 (cathodic curves).

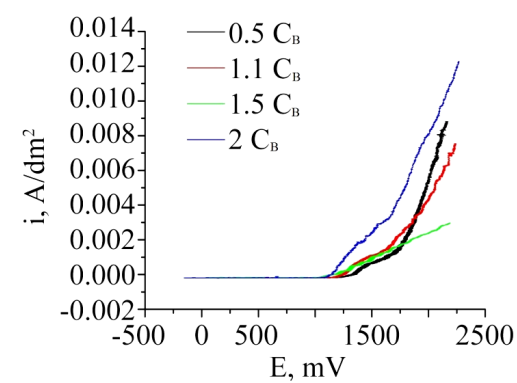

Fig. 1. Anodic polarization curves of the nickel electrode in electrolytes for nickel powder synthesis with different ammonia concentrations

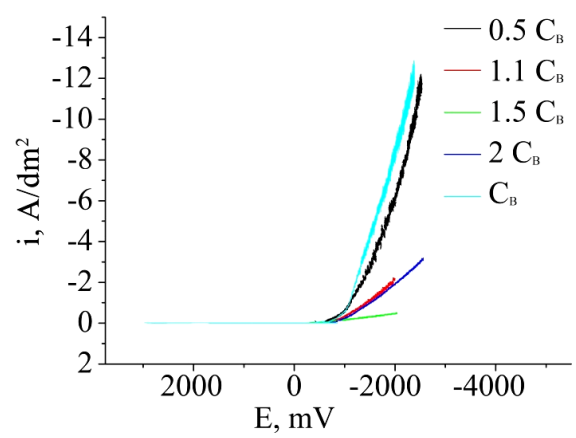

Fig. 2. Cathodic polarization curves in electrolytes for nickel powder synthesis with different ammonia concentrations

It should be noted that in the electrolyte for powder synthesis, the nickel anode is partly soluble. Polarization curves show plateaus of limiting passivation current. It should also be noted that at an ammonia concentration of $2 \mathrm{C}_{\mathrm{B}}(200 \%$ of the initial concentration), the current was significantly higher.

Lowering of ammonia concentration did not impact the cathodic curve significantly. However, after the cathodic curve was recorded, a green deposit of nickel hydroxyl-compounds was observed on the electrode. An increase in ammonia concentration leads to increased polarization, which should improve the powder quality.

5. 3. Study on the effect of complexing agent additive on characteristics of nickel powder

In order to maintain a stable concentration of complexed ions, it was decided to employ and additional complexing agent. As such additional complexing agent, Trilon B was added in the amount of $20 \%$ of the ammonia amount in the solution. In order to study the influence of Trilon B, nickel powders were prepared from electrolytes with and without 
Trilon B. It should be noted; that snow-water cooling was used for these experiments in order to create optimal temperature conditions. SEM images are shown in Fig. 3, 4.

It was discovered that the powder is composed of small spherical particles that form coral-like grains about 45$70 \mu \mathrm{m}$. These agglomerates easily break apart even with little effort applied. Particles of compact metal were observed in the sample prepared with Trilon B additive.

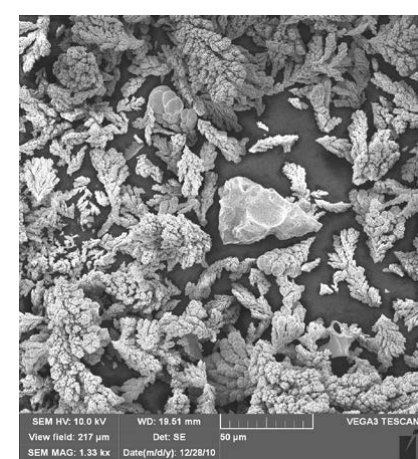

a

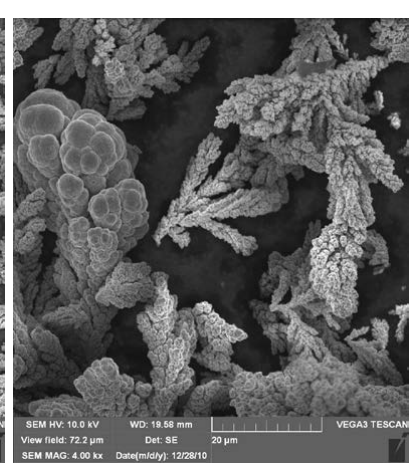

$b$
Fig. 3. SEM images of nickel powder prepared without Trilon B additive. Magnification: $a-\times 1,330, b-\times 4,000$

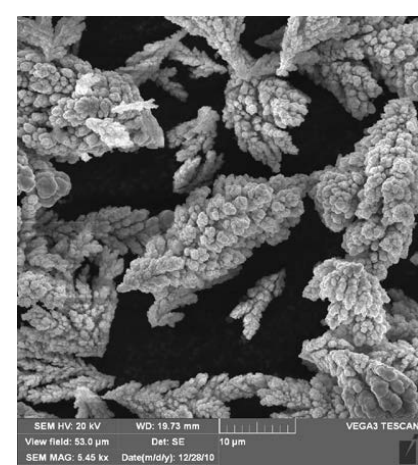

$a$

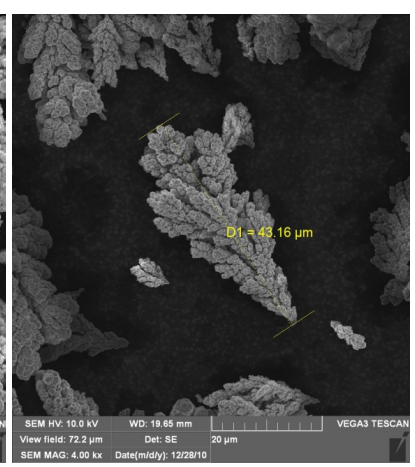

$b$
Fig. 4 SEM images of nickel powder prepared with

Trilon B additive. Magnification: $a-\times 1,330, b-\times 4,000$

Table 2 shows the composition of nickel powders prepared without and with Trilon B additive.

Table 2

Chemical composition of nickel powder samples

\begin{tabular}{|c|c|c|c|c|c|c|c|c|}
\hline \multirow{2}{*}{ Samples } & \multicolumn{8}{|c|}{ Element content, $\%$ mass } \\
\hline & \multicolumn{2}{|c|}{$\mathrm{Ni}$} & $\mathrm{Si}$ & $\mathrm{P}$ & S & $\mathrm{Fe}$ & Co & $\mathrm{Zn}$ \\
\hline $\begin{array}{c}\text { Sample with } \\
\text { Trilon B }\end{array}$ & \multicolumn{2}{|c|}{99.028} & 0.008 & 0.029 & 0.03 & 0.018 & 0.65 & 0.047 \\
\hline $\begin{array}{l}\text { Sample with- } \\
\text { out Trilon B }\end{array}$ & \multicolumn{2}{|c|}{99.054} & 015 & 0.024 & 0.022 & 0.015 & 0.72 & 0.055 \\
\hline \multirow{2}{*}{ Samples } & \multicolumn{8}{|c|}{ Element content, $\%$ mass } \\
\hline & As & $\mathrm{Cd}$ & Sn & $\mathrm{Ca}$ & $\mathrm{Sb}$ & $\mathrm{Pb}$ & $\mathrm{Bi}$ & $\mathrm{Al}$ \\
\hline $\begin{array}{c}\text { Sample with } \\
\text { Trilon B }\end{array}$ & 0.002 & 0.003 & 0.004 & 0.001 & 0.001 & 0.005 & 0.002 & 0.055 \\
\hline $\begin{array}{l}\text { Sample with- } \\
\text { out Trilon B }\end{array}$ & 0.004 & 0.002 & 0.002 & 0.001 & 0.001 & 0.006 & 0.003 & 0.076 \\
\hline
\end{tabular}

The content of admixtures in both samples is low. The content of $\mathrm{Ni}$ is $99.03-99.05 \%$. The primary admixture in nickel powder is Co $0.65-0.72 \%$. It should be noted that the addition of Trilon B does not significantly impact the composition of nickel powder.

The cathodic and anodic current yields have been determined for electrolytes with and without Trilon B additive (Table 3).

Table 3

Current yields for nickel powder synthesis

\begin{tabular}{|c|c|c|}
\hline \multirow{2}{*}{ Electrolyte } & \multicolumn{2}{|c|}{ Current Efficiency, \% } \\
\cline { 2 - 3 } & $\begin{array}{c}\text { Cathodic } \\
\text { (powder synthesis) }\end{array}$ & $\begin{array}{c}\text { Anodic } \\
\text { (nickel dissolution) }\end{array}$ \\
\hline Base & 41 & 5 \\
\hline Base with Trilon B & 35 & 8 \\
\hline
\end{tabular}

The values presented in Table 3 reveal that the addition of Trilon B leads to a decrease in current yield for nickel powder synthesis and increase in current yield for nickel anode dissolution.

\section{Discussion of the results of the study of electrochemical synthesis of nickel powder}

During the electrolysis for the synthesis of nickel powder at $i=100 \mathrm{~A} / \mathrm{dm}^{2}$, the Joule heating causes electrolyte temperature to rise. The results presented in Table 1 show that low electrolyte temperatures result in fine powder. This is in agreement with the data, according to which higher polarization leads to smaller particle size. And with an increase in temperature, the polarization is decreased. It was discovered that for the formation of nickel powder that is suitable for superalloy production, the electrolyte temperature should not exceed $50{ }^{\circ} \mathrm{C}$, which requires intense electrolyte cooling.

Analysis of the anodic polarization curves in the electrolyte with different ammonia contents (Fig. 1) revealed significant passivation of the nickel anode. All curves shows a pronounced passivation plateau, with the current density for nickel dissolution being insignificant $-1.5 \mathrm{~mA} / \mathrm{dm}^{2}$. It is likely explained by the basic media of the electrolyte, despite the presence of ammonia as a complexing agent. At the ammonia concentration of $50-150 \%$ of the base electrolyte, the behavior of the anodic curves is not affected significantly. Doubling of the ammonia content (200\% of the base electrolyte) leads to a significant increase in the nickel dissolution current because of complex formation, however, the absolute value of the current density is still low $-2.3 \mathrm{~mA} / \mathrm{dm}^{2}$.

The influence of ammonia concentration on the cathodic process is more significant. Increased concentration of ammonia leads to a significant increase in polarization because of more stable ammine complex, which results in a decrease of limiting current density. As a result, the particle size would decrease, resulting in a finer powder. Upon decreasing the ammonia concentration two times ( $50 \%$ of the base electrolyte), the polarization almost did not change. Upon a decrease in ammonia concentration in the highly basic cathodic layer of the electrolyte, a part of nickel would react with the formation of insoluble hydroxyl compound. Inclusion of hydroxides and basic salts significantly decreases the quality of the product, so it is necessary to maintain the ammonia concentration or introduce additional complexing agents.

Trilon B was introduced to the electrolyte for nickel powder synthesis in order to decrease the concentration of free nickel cations, lower the limiting current density and 
increase the polarization of nickel formation. This should also lead to the formation of finer powder. This hypothesis is further supported by the SEM results. It should be noted that particles of compact metal had been observed in the powder prepared from the base electrolyte. This is likely because of local drop in ammonia concentration or local heating. The presence of such compact metal particles decreases the quality of nickel powder for use in superalloys. Introduction of Trilon B prevents the formation of compact metal and allows preparing a powder with similar-sized particles that constitute agglomerates. The influence of Trilon B on the electrolysis process is supported by the data in Table 3 . Because of the formation of a sufficiently stable complex of Trilon $\mathrm{B}$ with $\mathrm{Ni}^{2+}$, the anodic current yield of nickel dissolution is increased and cathodic current yield is decreased.

The introduction of Trilon B almost doesn't affect the composition of the synthesized powder. In general, it should be noted that electrochemically synthesized nickel powder is of high purity. It should also be mentioned that the most significant impurity is Co, which is not harmful for the production of superalloys. Co on par with nickel is the most widespread metal binder in superalloys for various applications. Taking into account the discussions above, the synthesized nickel powders contain $99.67-99.77 \%$ of the component necessary for the production of superalloys.

It should be noted; that electrolysis parameters were studied using a laboratory model for the periodic process. However, modern trends in technology development lie in the transition to continuous processes, which provide better stability of the product's characteristics. Thus, before industrial implementation, it is necessary to develop a pilot reactor for continuous electrochemical synthesis and verify synthesis parameters.

\section{Conclusions}

1. It had been discovered that higher temperatures lead to lower powder dispersion. At an electrolyte temperature of $90-95^{\circ} \mathrm{C}$, nickel powder contains large amounts of compact metal. Lowering of temperature to $45-48{ }^{\circ} \mathrm{C}$ leads to the formation of ultrafine powder, though it contains some amount of compact metal.

2. It had been discovered, that an increase in ammonia concentration in the electrolyte increases the polarization of nickel formation and decreases the powder particle size. A decrease in ammonia concentration can lead to contamination of the powder with low-soluble hydroxyl compounds of nickel. It was proposed to introduce an additional complexing agent - Trilon B. It was discovered that the addition of Trilon B allows preventing the formation of compact nickel and enables to prepare $40-71 \mu \mathrm{m}$ long coral-like dendrites, composed of spherical particles that easily split apart. It was discovered that the introduction of Tilon B decreases the cathodic yield for the nickel formation from $41 \%$ to $35 \%$, while increasing the anodic current yield for nickel from $5 \%$ to $8 \%$.

3. The optimal conditions for electrolysis with the formation of ultrafine nickel metal powder, suitable for the production of superalloys had been determined: temperature below $45^{\circ} \mathrm{C}, \mathrm{pH}$ no lower than 11 (maintain with ammonia), addition of Trilon $\mathrm{B}$.

\section{References}

1. Baoguo H., Ze L., Jinping O. Piezoresistivity of Cement-Based Materials with Nickel Powder // Rare Metal Materials and Engineering. 2009. Vol. 38. P. 265-270

2. The Role of the Nickel Catalyst and Its Chemical and Structural Evolution During Carbon Nanopearl Growth / Pacley S., Mitchel W. C., Murray P. T., Anderson D., Smith H. E., Beck-Millerton E., Voevodin A. A. // Journal of Electronic Materials. 2012. Vol. 42, Issue 3. P. 417-425. doi: 10.1007/s11664-012-2367-0

3. Chou K.-S., Huang K.-C. Studies on the chemical synthesis of nanosized nickel powder and its stability // Journal of Nanoparticle Research. 2001. Vol. 3, Issue 2/3. P. 127-132. doi: 10.1023/a:1017940804321

4. Rheological properties of EP962NP nickel powdered superalloy under deformation in the two-phase region with industrial stamping rates and structural changes corresponding to deformation / Ryndenkov D. V., Perevozov A. S., Rybantsova E. N., Khomutov M. G. // Russian Journal of Non-Ferrous Metals. 2017. Vol. 58, Issue 2. P. 136-141. doi: 10.3103/s1067821217020110

5. ElRakayby H., Kim K. Deformation and densification behaviours of nickel-based superalloy during hot isostatic pressing // Powder Metallurgy. 2017. Vol. 60, Issue 4. P. 293-300. doi: 10.1080/00325899.2017.1298875

6. Antifriction and Construction Materials Based on Modified Phenol-Formaldehyde Resins Reinforced with Mineral and Synthetic Fibrous Fillers / Burmistr M. V., Boiko V. S., Lipko E. O., Gerasimenko K. O., Gomza Y. P., Vesnin R. L. et. al. // Mechanics of Composite Materials. 2014. Vol. 50, Issue 2. P. 213-222. doi: 10.1007/s11029-014-9408-0

7. Kotok V., Kovalenko V. The properties investigation of the faradaic supercapacitor electrode formed on foamed nickel substrate with polyvinyl alcohol using // Eastern-European Journal of Enterprise Technologies. 2017. Vol. 4, Issue 12 (88). P. 31-37. doi: 10.15587/1729-4061.2017.108839

8. Research of the mechanism of formation and properties of tripolyphosphate coating on the steel basis / Vlasova E., Kovalenko V., Kotok V., Vlasov S. // Eastern-European Journal of Enterprise Technologies. 2016. Vol. 5, Issue 5 (83). P. 33-39. doi: 10.15587/1729-4061.2016.79559

9. Advanced electrochromic $\mathrm{Ni}(\mathrm{OH}) 2 / \mathrm{PVA}$ films formed by electrochemical template synthesis / Kotok V. A., Kovalenko V. L., Kovalenko P. V., Solovov V. A., Deabate S., Mehdi A. et. al. // ARPN Journal of Engineering and Applied Sciences. 2017. Vol. 12, Issue 13. P. 3962-3977.

10. Kotok V., Kovalenko V. The electrochemical cathodic template synthesis of nickel hydroxide thin films for electrochromic devices: role of temperature // Eastern-European Journal of Enterprise Technologies. 2017. Vol. 2, Issue 11 (86). P. 28-34. doi: 10.15587/1729-4061.2017.97371 
11. Kotok V., Kovalenko V. Electrochromism of $\mathrm{Ni}(\mathrm{OH}) 2$ films obtained by cathode template method with addition of $\mathrm{Al}, \mathrm{Zn}, \mathrm{Co}$ ions // Eastern-European Journal of Enterprise Technologies. 2017. Vol. 3, Issue 12 (87). P. 38-43. doi: 10.15587/1729-4061.2017.103010

12. An Investigation of Direct Powder Forging of Nickel Superalloy FGH96 / Fang S., Shi Z. S., Bai Q., Jiang J. Y., Wang S. Y., Lin J. G. // Key Engineering Materials. 2016. Vol. 716. P. 793-799. doi: 10.4028/www.scientific.net/kem.716.793

13. Composite $\mathrm{WC}-35 \% \mathrm{Ni}$ produced from ultrafine $\mathrm{WC}+\mathrm{NiO}$ powders. II. mechanical properties / Tolochin A. I., Laptev A. V., Okun I. Y., Kovalchenko,M. S. // Powder Metallurgy and Metal Ceramics. 2012. Vol. 50, Issue 9-10. P. 625-631. doi: 10.1007/s11106012-9368-7

14. Ni-Based Superalloys / S. A. Sajjadi (Ed.). Ferdowsi University of Mashhad, 2013.

15. Aerospace Materials and Material Technologies. Vol. 1. Aerospace Materials / N. Eswara Prasad, R. J. H. Wanhill (Eds.). Singapore: Springer, 2017. doi: 10.1007/978-981-10-2134-3

16. Aerospace Materials and Material Technologies. Vol. 2. Aerospace Material Technologies / N. Eswara Prasad, R. J. H. Wanhill (Eds.). Singapore: Springer, 2017. doi: 10.1007/978-981-10-2143-5

17. Escudero G., Espinoza E., Rao F. Chemical Precipitation of Nickel Species from Waste Water // International Research Journal of Pure and Applied Chemistry. 2017. Vol. 15, Issue 2. P. 1-7. doi: 10.9734/irjpac/2017/37905

18. Kovalenko V., Kotok V. Selective anodic treatment of W(WC)-based superalloy scrap // Eastern-European Journal of Enterprise Technologies. 2017. Vol. 1, Issue 5 (85). P. 53-58. doi: 10.15587/1729-4061.2017.91205

19. The Kinetics of Precipitate Dissolution in a Nickel-Base Superalloy / Semiatin S. L., Levkulich N. C., Saurber A. E., Mahaffey D. W., Payton E. J., Senkov O. N. // Metallurgical and Materials Transactions A. 2017. Vol. 48, Issue 11. P. 5567-5578. doi: 10.1007/s11661-017-4322-4

20. Rozário A., Silva e Silva R. K., Freitas M. B. J. G. Recycling of nickel from NiOOH/Ni(OH)2 electrodes of spent Ni-Cd batteries // Journal of Power Sources. 2006. Vol. 158, Issue 1. P. 754-759. doi: 10.1016/j.jpowsour.2005.08.055

21. Kotok V., Kovalenko V., Malyshev V. Comparison of oxygen evolution parameters on different types of nickel hydroxide // Eastern-European Journal of Enterprise Technologies. 2017. Vol. 5, Issue 12 (89). P. 12-19. doi: 10.15587/1729-4061.2017.109770

22. Kovalenko V., Kotok V. Definition of effectiveness of - $\mathrm{Ni}(\mathrm{OH}) 2$ application in the alkaline secondary cells and hybrid supercapacitors // Eastern-European Journal of Enterprise Technologies. 2017. Vol. 5, Issue 6 (89). P. 17-22. doi: 10.15587/17294061.2017.110390

23. Kovalenko V., Kotok V. Obtaining of Ni-Al layered double hydroxide by slit diaphragm electrolyzer // Eastern-European Journal of Enterprise Technologies. 2017. Vol. 2, Issue 6 (86). P. 11-17. doi: 10.15587/1729-4061.2017.95699

24. Kovalenko V., Kotok V. Study of the influence of the template concentration under homogeneous precepitation on the properties of $\mathrm{Ni}(\mathrm{OH})_{2}$ for supercapacitors // Eastern-European Journal of Enterprise Technologies. 2017. Vol. 4, Issue 6 (88). P. 17-22. doi: $10.15587 / 1729-4061.2017 .106813$

25. Kotok V., Kovalenko V. Optimization of nickel hydroxide electrode of the hybrid supercapacitor // Eastern-European Journal of Enterprise Technologies. 2017. Vol. 1, Issue 6 (85). P. 4-9. doi: 10.15587/1729-4061.2017.90810

26. Förster H., Wolfrum C., Peukert W. Experimental study of metal nanoparticle synthesis by an arc evaporation/condensation process // Journal of Nanoparticle Research. 2012. Vol. 14, Issue 7. doi: 10.1007/s11051-012-0926-1

27. Nickel Powders Recycled from Invar Scrap by Magnesiothermic Reduction / Lee J.-S., Lee D.-W., Lee H.-S., Yun J.-Y., Wang J.-P. // Journal of Nanoscience and Nanotechnology. 2014. Vol. 14, Issue 12. P. 9037-9041. doi: 10.1166/jnn.2014.10064

28. Yagi R., Okabe T. H. Recovery of Nickel from Nickel-Based Superalloy Scraps by Utilizing Molten Zinc // Metallurgical and Materials Transactions B. 2016. Vol. 48, Issue 1. P. 335-345. doi: 10.1007/s11663-016-0854-z

29. Production of nickel powder by the titanium redox method and its application to conductive materials / Inazawa S., Majima M., Koyama K., Tani Y., Toshioka H., Osoegawa M., Kashihara H. // Journal of Applied Electrochemistry. 2008. Vol. 38, Issue 9. P. 1211-1216. doi: 10.1007/s10800-008-9535-1

30. Study on Preparation Technology of Nickel Powder with Liquid Phase Reduction Method / Lei L., Jinghong D., Guoyou G., Jikang Y., Jiamin Z., Yichun L., Jianhong Y. // Rare Metal Materials and Engineering. 2015. Vol. 44, Issue 1. P. 36-40. doi: 10.1016/s18755372(15)30008-4

31. Synthesis and electromagnetic absorption properties of micro-nano nickel powders prepared with liquid phase reduction method / Yu Y., Ma H., Tian X.-X., Du H.-L., Xia S., Qu S.-B. // Journal of Advanced Dielectrics. 2016. Vol. 06, Issue 03. P. 1650025. doi: $10.1142 / \mathrm{s} 2010135 \times 16500259$

32. Şişman İ., Tütünoğlu Ç., Aydın A. Surfactant-assisted polyol preparation of nickel powders with different morphologies // Open Chemistry. 2008. Vol. 6, Issue 2. doi: 10.2478/s11532-008-0015-6

33. Nechayev Y. A., Nikolenko N. V. An adsorption mechanism for supergene gold accumulation // Geochemistry International. 1988. Vol. 25, Issue 11. P. 52-56.

34. Production of nickel powder by the titanium redox method and its application to conductive materials / Inazawa S., Majima M., Koyama K., Tani Y., Toshioka H., Osoegawa M., Kashihara H. // Journal of Applied Electrochemistry. 2008. Vol. 38, Issue 9. P. 1211-1216. doi: 10.1007/s10800-008-9535-1

35. Forsman J., Tapper U., Auvinen A., Jokiniemi J. Production of cobalt and nickel particles by hydrogen reduction // Journal of Nanoparticle Research. 2007. Vol. 10, Issue 5. P. 745-759. doi: 10.1007/s11051-007-9304-9

36. Bhattacharya M. Chemical Synthesis and Characterization of Nickel Powder // Metallurgical and Materials Transactions B. 2010. Vol. 42, Issue 2. P. 380-384. doi: 10.1007/s11663-010-9459-0 
37. Kurlov A. S., Gusev A. I., Rempel A. A. Morphology Of Ultrafine Cobalt And Nickel Powders // Reviews on Advanced Materials Science. 2012. Vol. 32, Issue 1. P. 52-60.

38. Kareem T. A., Kaliani A. A. Glow discharge plasma electrolysis for nanoparticles synthesis // Ionics. 2011. Vol. 18, Issue 3. P. 315-327. doi: 10.1007/s11581-011-0639-y

39. Tokushige M., Nishikiori T., Ito Y. Synthesis of Ni nanoparticles by plasma-induced cathodic discharge electrolysis // Journal of Applied Electrochemistry. 2009. Vol. 39, Issue 10. P. 1665-1670. doi: 10.1007/s10800-009-9856-8

40. Preparation of nanosized nickel powder by direct-current electrolysis combined with high-voltage spark discharge / Ibishev K. S., Malyshev V. P., Kim S. V., Sarsembaev B. S., Egorov N. B. // High Energy Chemistry. 2017. Vol. 51, Issue 3. P. $219-223$. doi: 10.1134/s0018143917030055

\begin{abstract}
Встановлено вплив добавок метакаоліна $і$ каоліна на форлування мікро- макроструктури й властивостей лугоактивованих илакових иементів $і$ бетонів. Проведено порівняльне дослідження впливу цих добавок. Встановлено, що введення 2,5-5,0 \% добавки каоліну має більш ефективний вплив на процеси структуроутворення $і$ властивості, ніж добавка метакаоліну. Окрім того, заміна добавки метакаоліну каоліном спрощує технологічний процес виробництва й суттєво знижує вартість цементу и бетону

Ключові слова: бетон, каолін, лугоактивований цемент, метакаолін, міцність при стиску, морозостійкість

$$
\square
$$
\end{abstract}

Исследовано влияние добавок метакаолина и каолина на формирование микро- макроструктуръ и свойств щелочеактивированных илаковых цементов и бетонов. Проведено сравнительное исследование влияния этих добавок. Установлено, ито введение 2,5-5,0\% добавки каолина оказывает более эффективное влияние на процессы структурообразования и свойства, чем добавка метакаолина. Кроме того, замена добавки метакаолина каолином упрощает технологический процесс производства и существенно снижает стоимость цемента и бетона

Ключевые слова: бетон, каолин, щелочеактивированный цемент, метакаолин, прочность при сжатии, морозостойкость

\section{口-}

\section{Introduction}

Environmental concerns arising from cement production due to $\mathrm{CO}_{2}$ emissions and high energy consumption required for high-temperature firing can be eliminated by a wider use of blended and composite cements [1].

One of such cements is the alkali-activated cement [2] (further, the AAC) which attracted an interest of scientists and industry worldwide [3] and promoted its fast development in recent years [4].

The AACs vary in proportions of basic oxides in the system $\mathrm{N}(\mathrm{K})_{2} \mathrm{O}-\mathrm{CaO}-\mathrm{Al}_{2} \mathrm{O}_{3}-\mathrm{SiO}_{2}-\mathrm{H}_{2} \mathrm{O}$ and, according
UDC 691.5

DOI: $10.15587 / 1729-4061.2018 .119624$

\section{A COMPARATIVE STUDY ON THE INFLUENCE OF METAKAOLIN AND KAOLIN ADDITIVES ON PROPERTIES AND STRUCTURE OF THE ALKALI-ACTIVATED SLAG CEMENT AND CONCRETE}

\author{
P. Krivenko \\ Doctor of Technical Sciences, Professor* \\ E-mail: pavlo.kryvenko@gmail.com \\ O. Petropavlovsk y i \\ $\mathrm{PhD}$, Senior Researcher* \\ O. Kova I c h u k \\ $\mathrm{PhD}$, Senior Researcher* \\ E-mail: kovalchuk.oyu@gmail.com \\ * Scientific Research Institute for \\ Binders and Materials \\ Kyiv National University of \\ Construction and Architecture \\ Povitroflotskiy ave., 31, Kyiv, Ukraine, 03037
}

to this, can be divided into three types: high, low and medium-calcium alkali-activated cements [5]. This predetermines a phase composition of the hydration products, hence, properties of the cements and concretes on their basis [6].

The most widely used are the alkali-activated cements with metallurgical slags as an aluminosilicate component the alkali-activated slag cements (further, the AASCs).

Since metallurgical slags vary in chemical composition [7], correcting additives are to be added in order to give the required (target) properties to a cement stone [8]. These additives can affect both properties of the alkali-activated cement paste and alkali-activated cement concrete due to more 